\title{
Soil carbon persistence linked to mineralogy across sub-Saharan
} Africa

\section{Other Conference Item}

\section{Author(s):}

von Fromm, Sophie Franziska (D); Hoyt, Alison M.; Butler, Benjamin M.; Berhe, Asmeret Asefaw; Doetterl, Sebastian (D); Haefele, Stephan M.; McGrath, Steve P.; Shepherd, Keith D.; Six, Johan; Towett, Erick K.; Winowiecki, Leigh A.; Trumbore, Susan E.

Publication date:

2021

Permanent link:

https://doi.org/10.3929/ethz-b-000521961

Rights / license:

Creative Commons Attribution 4.0 International

Originally published in:

EGUsphere, https://doi.org/10.5194/egusphere-egu21-10703 
EGU21-10703

EGU General Assembly 2021

(c) Author(s) 2021. This work is distributed under

the Creative Commons Attribution 4.0 License.

\section{Soil carbon persistence linked to mineralogy across sub-Saharan Africa}

Sophie F. von Fromm ${ }^{1,2}$, Alison M. Hoyt ${ }^{1}$, Benjamin M. Butler ${ }^{3}$, Asmeret Asefaw Berhe ${ }^{4}$, Sebastian Doetterl ${ }^{2}$, Stephan M. Haefele ${ }^{5}$, Steve P. McGrath ${ }^{5}$, Keith D. Shepherd ${ }^{6}$, Johan Six ${ }^{2}$, Erick K. Towett ${ }^{6}$, Leigh A. Winowiecki ${ }^{6}$, and Susan E. Trumbore ${ }^{1}$

'Department of Biogeochemical Processes, Max-Planck-Institute for Biogeochemistry, Jena, Germany (sfromm@bgc-

jena.mpg.de)

${ }^{2}$ Department of Environmental System Science, ETH Zurich, Zurich, Switzerland

${ }^{3}$ The James Hutton Institute, Aberdeen, Scotland

${ }^{4}$ Department of Live and Environmental Sciences, University of California Merced, Merced, CA, USA

${ }^{5}$ Department of Sustainable Agriculture Sciences, Rothamsted Research, Harpenden, England

${ }^{6}$ International Centre for Research in Agroforestry, Nairobi, Kenya

Recent compilations of global soil radiocarbon data suggest that current Earth System Models underestimate the mean age of soil carbon (C). The discrepancy between data-derived estimates and model calculations might be due to an inadequate representation of processes that control $C$ persistence in soils - especially in understudied regions.

Here, we investigate the relationships between soil mineralogy, soil properties, climate and radiocarbon $\left(\Delta^{14} C\right)$ in soils sampled as part of a comprehensive soil survey (AfSIS) for sub-Saharan Africa. A total of 510 samples were analyzed, comprised of soils collected from two depths $(0-20 \mathrm{~cm}$ and $20-50 \mathrm{~cm})$ at 30 sites in 14 countries. To determine soil mineralogy, we analyzed Xray powder diffraction (XRPD) data, which provides a precise and detailed mineralogical signature of each soil sample. The studied soil profiles vary greatly in their mineralogy, reflecting a diverse range of parent materials and soil forming factors.

The median soil $C$ age is 182 years in the topsoils and 563 years in the subsoils, corresponding to a total $\Delta^{14} C$ value range of -432 to $95 \%$. In general, $\Delta^{14} C$ values decrease (older mean $C$ ages) with increasing clay particle size fractions. This corresponds to an increase in short range-order minerals expressed as oxalate-extractable aluminum and iron $\left(\mathrm{Al}_{\mathrm{ox}}\right.$ and $\left.\mathrm{Fe}_{\mathrm{ox}}\right)$. Separately, mineralogically defined variables - derived from the XRPD data using principal component analysis - are found to correlate strongly with a range of soil properties $(\mathrm{pH}$, weathering status, exchangeable calcium, $\mathrm{Al}_{\mathrm{ox}}$ and $\mathrm{Fe}_{\mathrm{ox}}$, and soil texture) and climatic variables (aridity index and mean annual temperature). This provides a holistic assessment of the processes that have formed each soil along with the properties that it currently exhibits. Our analyses with random forests show that these XRPD-derived mineralogical variables alone can explain up to $30 \%$ of the variation in $\Delta^{14} \mathrm{C}$ across sub-Saharan Africa. They also allow the identification of specific minerals that contribute to this variation and how they are linked to the $\mathrm{C}$ mean age of the soil. In conclusion, our results suggest that soil mineral data can help to better understand $C$ persistence in 
subtropical and tropical soils. 